\title{
Sciendo
}

\section{"With All The Ghosts that Haunt the Park...": Haunted Recreation in Brent (Ontario)}

\author{
IAN PUPPE \\ Department of Native Studies, \\ Brandon University, Canada \\ puppei@brandonu.ca
}

\begin{abstract}
When I first visited Brent, the defunct logging village, now campgrounds in the northern reaches of Algonquin Provincial Park I went searching for ghost stories. Often described as a "ghost town," Brent has been occupied since the earliest days of logging in the Ottawa River/Kiji Sibi Valley and holds an important place in the oral history of the Park. The village was a place where many died after violent accidents during the timber rush of the eighteenhundreds, where Algonquin Anishinaabe Peoples had camped and likely held a village of their own prior to colonization. Brent was once a bustling community, the former site of the Kish-Kaduk Lodge and an important railway stopover during the First World War. Further, Brent was home to the last year round resident of the Park. Mr. Adam Pitts, known to many local cottagers as the "Mayor" passed away in his home in 1998 one year after the railroad tracks were removed by the Canadian National Railway Company and the electricity was shut off. Now his cottage is a ruin some claim to be haunted by the Mayor's restless ghost. And there are other ghost stories I heard in Brent that haunt the edges of the colonial imagination, stalking unwary travellers as they meander through what they sometimes assume to be "pristine wilderness." Common patterns of self-apprehension and identity formation associated with tourism and heritage management in Algonquin Park are imbued with nationalist value through a prismatic complex of cultural appropriation, the denial of complicity in colonial violence, and the contingent obfuscation of Indigenous presence and persistence in the area, a process I call haunted recreation. Countering this complex is critical for working past the historical and intergenerational trauma associated with Canadian settlercolonialism and the contemporary inequities of Canadian society.
\end{abstract}

KEY WORDS: Algonquin Anishinaabe, Algonquin Park, ghost stories, haunted recreation, identity, indigenous peoples, nationalism, settler-colonialism 


\section{Introduction}

On my first visit to Brent, I was unsure about what to expect from the campgrounds and former logging village in the northern area of Algonquin Park known for its isolation and eccentricities. Located along the Petawawa River on the north shore of Cedar Lake, Brent once sat on a railway line that carried people and commodities (such as wheat and timber) from Canada's furthest eastern and western reaches. Brent was used by Algonquin Anishinaabe as a hunting territory and hosted a small fishing village for hundreds of years prior to colonization of the area. In the mid-1800's during the height of the timber boom Brent was home to as many as 600 people and hosted dignitaries, celebrities and politicians at the famed Kish-Kaduk Lodge making the actual population of the area closer to onethousand including those more "transient" visitors. Now Brent is an interior jump-off point for adventurous canoe enthusiasts, a seasonal cottage community and a quiet place for campers to escape the pace and pressures of the city and the more crowded Highway \#60 corridor nearer to the province's larger population centres. As the plaques erected during my first stretch of fieldwork in 2012 attest, it is also known as a place to "step back in time." Until relatively recently it was common to find references to the "ghost town" of Brent even in the literature released by Ontario Parks, the governmental agency responsible for the administration and maintenance of the Park under the Ministry of the Environment, Conservation and Parks. As far as the Park authorities knew, I was there to do research on history, nostalgia and memory. But my main interest was ghost stories as intersections of precisely these things (Gordon 1997), and as instantiations of personal experience that went beyond explanation; as ways of "talking back" against master-narratives, prying open some "room for manoeuvre" (Stewart 1996). And there are other ghost stories I heard in Brent that haunt the edges of the colonial imagination, stalking unwary travellers as they meander through what they sometimes assume to be "pristine wilderness." Common patterns of selfapprehension and identity formation associated with tourism and heritage management in Algonquin Park are imbued with nationalist value through a prismatic complex of cultural appropriation, the denial of complicity in colonial violence, and the contingent obfuscation of Indigenous presence and persistence in the area, a process I call haunted recreation. Countering this complex is critical for working past the historical and intergenerational trauma associated with Canadian settler-colonialism and the contemporary inequities of Canadian society.

Wandering around the village and taking in the sights of the small community, I immediately met a few of the most visible locals. Marie and her husband Jim Joyce were the campground "hosts," and they greeted everyone who came down the road as if they were old friends with the oftentimes baffling question "Are you lost?" The Outfitters' shop, a mix of museum and 
last-stop variety store in the bush, was operated by Jake Pigeon, a wizened man of at least sixty who gruffly nodded a hello to me, bare-chested from the behind the counter. His partner in the business Rob, a friendly, but tough looking, good-humored, dark-haired man of about forty-five, was also bare-chested most of the time and I soon learned that going shirtless was an option for men anywhere and anytime in Brent. Exploring the Outfitters' shop I found an array of pictures pinned to corkboards showing Jake and Rob's families, frolicking and fishing in the lake. Some pictures and newspaper clippings were of people from Brent's past, characters from the days of logging, or early rangers and important figures from the Park's celebrated history; Feminist Camp Operator Fanny Chase, Former Ontario Premiere Leslie Frost, and Algonquin Elders William and August Commanda. But a few others pictured less well-known figures. One of those was Adam Pitts, the last year-round resident of the village, a reclusive fiddler facetiously referred to by cottagers and locals as the "Mayor of Brent."

Jake told me where Mr. Pitts had lived for his whole life, in a house that was then falling to ruins just behind another larger cottage across the rail-bed from the shop. On the walk over I came across a pet cemetery which added a dimension of uncomfortable familiarity to the place wedged into an area between the cottages in a tall, uncut section of grasses and "weeds." Jake told me to feel free to explore. My notes from then quote him telling me to "ignore the fences," but I couldn't bring myself to cross them when I got to the building that had been Mr. Pitt's home. I had no desire at all to enter.

\section{Roses and Remembrance}

The roses stretched out across the barbed wire and the thorns on the leggy vines seemed primed and ready to pierce the toughest of skin. A few small rosebuds began to let their internal scarlet peek through the slightly split leaves holding them back. The roses stood out against the background of more commonly found invasive domesticate species; the wild grape (Vitis spp.) and the deadly nightshade (Atropa belladonna). In the golden afternoon sunshine, I felt that the thorns and the barbs on the fence were nearly indistinguishable from one another, and the thought of getting caught and injured hours from emergency responders while climbing through made me wonder if Jake had told me to ignore the fences as a sort of test; would I climb them, risking injury in a reckless attempt to see what was inside of a ruin, or would I hear his words as a warning?

Jake told me that when Mr. Pitts passed away some people who claimed to be family showed up and began exploring the house for things that they could take. Apparently, they were so 
convinced that the old man was stashing cash away that they knocked holes in the walls, ceiling, and floorboards. Weakening the structure, by the time I came upon the ruin the ceiling had fallen in and the floors were covered in holes and rotten debris. Jake said he didn't think there was anything there, but he said he thought the mayor had plenty of money, and he had always paid everyone who helped him out very kindly. He hinted that the money might be buried somewhere near the house, or further down the railway bed in a cache, perhaps testing me to see what my true motives were for asking such awkward questions. Rob joked that he was only there to find the treasure and he was waiting for Jake to give up the secret. Rob told me he sometimes wandered around the campgrounds sniffing for the scent of coal oil. He said that the mayor had used coal oil to repel animals and preserve foodstuffs, and covered almost everything he had in the stuff, including most of his clothes.

\section{Uneasy Encounters}

After hearing the stories and visiting the ruins of Mr. Pitts cabin, I crossed paths with a trio of sturdy men while leaving the shop, cut from the same cloth as Rob, preparing for a few days of fishing and a few nights of drinking around the campfire, catching up with good friends. These trips are some of the most popular for visitors to the campgrounds, who often bring trailers and many of the amenities of home with them down the rough gravel logging road that links Brent to a section of the Trans-Canada Highway called Provincial Highway \#17. These men towed a very nice twenty or so foot fishing boat behind a Recreational Vehicle that could easily sleep six adults of average size. These types of camping/fishing trips though often not considered to be "high end," cost a great deal with fuel, insurance, leases, maintenance, and other expenses adding up quickly. Adding in the additional expenses associated with guides and other costs these trips can cost thousands of dollars, though most weekend trippers and canoeists do their best to keep them under a few hundred. Trailers and boats are evidence of regular camping and angling and so show the willingness to spend thousands of dollars annually on what many consider to be leisure activities.

A demonstration of relative privilege, these trailers and trips are often described as "glamping," a neologism of camping and glamour focused less on the experience and more on the pageantry of style. Certainly not necessary for most, these trailers provide the comforts of a home, including beds, small kitchens, and washrooms. While those who camp in tents stay on mattresses and cots closer to the ground and less oriented towards comfort than on portability, these trailers sometimes include laundry and other appliances allowing the trailer to assume the role of a mobile cottage, and those who camp in them to stand out as unusually 
clean compared to their fellows. Trailers do have the advantage of allowing much greater access to remote locations for those with mobility issues, yet, the environmental impact they embody is undeniably more intense than tents and ultra-light options such as hammocks. While not by any means a universal or homogenous description of these differences, tent campers more often find themselves sitting around the campfire in the evening watching the stars, those with trailers far more commonly retreat into the trailer in the evening to watch a movie or play a video game on an electronic device. Those campers who stay in trailers seem less focused on the immersive aspects of a camping trip far from home and more on maintaining a uniform level of comfort while exploiting the amenities the Park offers. The sacrifice being those experiences born from being less sheltered from one's surrounding environment, and of having to make do with fewer luxuries.

Animosities between the two groups of campers broadly writ are nothing new. Those who either prefer, or by cost are forced, to use tents often complain of the increased noise and numbers of campers that come with these trailers. Many who bring trailers with generators for electricity regularly play radios, run generators into the night, and use much larger vehicles to tow these trailers, leaving those who tent camp listening to the gas-powered machines overnight while those in the trailers enjoy air conditioning in the forest. Certainly, evidence of increasingly entrenched class divisions in Canada, these animosities have only intensified over recent years with the growing presence of trailers in the Parks, and the increased popularity of camping and other "stay-cations" (another popular neologism combining the notion of the vacation with a more local stay) under the context of the current pandemic situation brought on by Covid-19. During my research in Brent over the years of 2009-2012 I found that camp sites often went unoccupied, even over weekends, with the campgrounds regularly being at $40-70 \%$ capacity. Yet more recently it has become common to have to arrange a booking months in advance to secure a site for the desired period with the increased pressure on the parks system in Ontario and elsewhere in Canada.

The trio of men gave me suspicious looks as they passed me entering the outfitters shop. I felt uneasy but then thought about how strange it must seem that a man in his mid-thirties would be alone in the campgrounds with no watercraft. Cedar Lake is a known fishing hole, popular with locals from the North Bay region and stocked with a variety of game species annually. The first man nodded, and I returned the acknowledgement as I passed, heading back down the trail towards my campsite at the end of the campgrounds. 


\section{Manufacturing Memorial}

Later that day I spent some time exploring the railway bed. The tracks had been removed in 1997 and the electricity to the area was shut off at the same time, one year before Adam Pitts' death. I wandered past the Outfitters' shop towards the old cabins and back towards my campsite. I then noticed something that had slipped my attention while setting up camp. A large white cross made of metal pipes stood at the end of a path that led into some brush. It had not been visible from my campsite, though I was camped right beside it.

I later explored information about the area found on a small plaque and learned that the grave was said to contain as many as nine bodies from young men who had died during the timber drives of the early 1900's. This story participates in the official metanarrative describing the Park's justification and its' place in the national-cultural imaginary (Ivy 1998, 3) as a home of loggers, pioneers, and other so-called "true" Canadians, and which works to obfuscate the historical presence of Indigenous Peoples in the place, and to sanitize the story of their dispossession. But just after I left for my site a man arrived with two boys, aged perhaps 8 and 10 years old. He was about sixty years old in appearance, grey haired, and somewhat unkempt, even beyond being "bushed," as campers sometimes describe the exhausted and untidy appearance of a person who has recently emerged from the woods. While talking with the boys, his nephews, he said

“There weren't no nine bodies in there... No. There's one though. He's my uncle. I know "cause I buried him. This is all just memorial."

He called the man in the grave "Uncle Romeo," and the mention of the name drew strange reactions from the two boys, causing them to look at each other confusedly.

In a daydream flash I thought for a moment the two boys' reactions may have been due to the man's use of the name "Romeo." Maybe they had never heard it before and this name was new to them, an ancestor un-remembered? Or perhaps they were caught off guard because their uncle, the man speaking to them, was named Romeo, and was inferring that he himself was in the grave? I thought for a fleeting moment I had dreamed up the whole encounter, and that they had all been ghosts of past cottagers, campers, villagers. visitors to Brent, lost to memory, sauntering through my surreal afternoon visions. I never got a chance to ask them any questions, and they walked off on a path beyond the graves in a direction I had not yet explored. I never saw them again, though from the boy's clothes I later saw on the laundry line I was sure they were staying in the old box car home that sat near the former railway bed, and that had been converted generations before. It was covered with layers of peeling shingles and reinforced framing where the original timber rotted away, and much of 
the insulation contained asbestos. The cottage had the same worn and rugged atmosphere of Pitts' though the roof had yet to cave in. It gave off the same aura of anachronistic timelessness the old man had when talking about the graves, of the outfitters' shop, and of the sign hanging to mark "Downtown Brent," an absurdity in such a quiet and often nearly vacant place.

\section{A Ghost Story}

Later that evening I was sitting at the picnic bench on my campsite reading as the three men came by to check out the grave and to read the plaque that had been recently installed. They nodded a greeting on their way past, and when they returned one of the men spoke up and asked if I was alone. I said yes, and he asked if I "wanted to come by their site for a beer." I agreed, gathered my keys and camera, and followed them to a site deeper in the bush away from the clearing at the western end of the campgrounds where my site was located. While walking they told me that they were in Brent for an annual fishing trip they made together for roughly twenty years. They said they were "one man down" that year because the fourth member of their group had suffered a heart attack and was not willing to be so far from medical help.

The three had similar body shapes and sizes and were of roughly the same height, at about five foot ten and 220-240 lbs. Barrel-chested, and with large strong hands worn from hard work, the three looked as if they had been drinking for hours already by the evening. One had dark hair, thinning and short with a dark beard and moustache. Another had a ruddy sunkissed complexion, bright blue eyes and wore a red baseball cap. He was the spokesperson for the group, speaking the most and laughing the loudest, he was the most outgoing and gregarious, but also most likely to argue and easiest to anger, member of the party. The last of the three wore glasses over his fading blue eyes, and the grey ponytail pulled back over his head was the same color as his long scraggly beard and unkempt moustache. He was quieter than the others, and spoke less often, smoking cigarettes most of the time, listening.

They already had a small fire going and the smoking man put some more logs on to stoke it while the man with the dark hair and beard went to the cooler tied down to the end of the trailer hitch. After pulling four cans out of the ice he handed out the beer and sat himself down on the picnic bench, demanding that I take one of the more comfortable lawn chairs they brought in with them. 
After I sat, one of the men looked at me and asked what I was doing in Brent. I told him I had come to do research on the history of the area, and the ways people remembered certain things and not others. They pressed me further and I admitted I became interested in Brent when I heard that it was known as a "ghost town." I explained the past Indigenous occupancy of the area, mentioned the land claim that had been first pursued by the Algonquin in 1982, and the ways that some guidebooks mentioned the Algonquin People as if they were gone, perhaps even "extinct." I told them that I felt this played into how people described the place as a ghost town, and that it interfered with the possibility of finding better ways to live together. I told them about the trouble I had in securing clearance to do research in the Park, and how the Park Biologist had told me that "my insinuation that Brent is haunted [was] unfounded and research framed in this manner will not be approved" (Puppe 2012, unpublished).

As explored by Tiya Miles (2015) in her work on the antebellum and post-slavery South and tourism to areas marked by tragedy and loss, social scientists and others explore the affective and intellectual dimensions of culturally constricted choices to memorialize and relate to various spaces in ways that demonstrate much of our tacit understandings and cultural upbringings. Miles work highlights the "dark" aspects of a post-slavery American nationalcultural imaginary by analyzing various cases of would be hauntings and the stories that linger long after violent events when people visit as tourists and travellers, or work in and depend on these narratives to sustain lifestyles deeply entangled with these approaches to memory. Pointing out that many of these visitors seek "sanitized" versions of events which help them elide awareness of the most violent and grim happenings in these places, Miles describes the ways in which these stories work to shore up the metanarratives of the nationstate. But these most grim details are not always hidden or ignored, and perhaps, are more often directly sought in a culture wrought by overexposed visual cues, and hyperexhibitionism. Similar to the descriptions of ghost tales told in the mining towns of Ontario's near north by Pamela Stern (2019), the story I soon heard made no effort to elide violence, and rather sought to elicit a particular response to the mention of violence counter-posed to the images of serenity that predominate representations of the Park.

We had a laugh about how "some folks can be so literal." But then the man in the red hat, who seemed less at ease with the conversation, tried to change the conversation. Jarred by the topic of Indigenous Peoples' continued and increasingly more visible presence in the area, he told me a story that he said his father had told him when he first visited Brent as a kid. It went something like this:

"There used to be a lodge just a little further west along the railroad tracks in a place called 
Government Park, about a fifteen minute walk away. It was called Kish-Kaduk. There was a room in the lodge that doubled as a dining room and a speakeasy where sometimes people would gather for libations.

One evening while his father was having some drinks with friends a man burst through the doors and exclaimed that he had just found a body down by the shore of the lake. They rushed outside to find a man dead from an apparent blow to the head. He was sprawled on the beach beside a broken paddle and there was a line in the sand where a canoe must have pushed off.

The man's father spoke up and said that he had seen two men arguing near that spot before he had come into the lodge. One of the two men who had been arguing came in shortly after him, but he didn't see his face. The tall, scruffy, dark haired stranger came in, ordered a drink and sat with his back to the room studying a map. He looked tired. The owner of the lodge asked him to describe the man again, and it became clearer that something ominous was happening. One of the man's father's friends corroborated his story about the argument on the beach, saying that he too had seen the men unloading their canoe and had heard some loud voices, but had entered just before his friend.

At this point the owner of the lodge became anxious, repeatedly asking the men to describe the man they had seen. He was tall, almost six feet, with dark hair, longer than most; almost grown past his shoulders. He wore a dark green jacket and dark pants, and he had a slight limp. The owner of the lodge went pale.

He said the he had not served anyone else after the man's father. No one had come in after the man's father, and there was no one at that table.

They rushed back inside and indeed found no one. Then the owner spoke again and told them that the man in question, the man who had likely killed his travelling companion, was someone he thought he recognized from their descriptions. The man the owner knew was a guide who took visitors to the Park on fishing trips. He was an "Indian," a man from the local Algonquin Nation.

But, the lodge owner said, it couldn't have been him that they saw, because, of course, he had been dead for at least ten years."

When he finished the story, he paused and then drank the remaining half of his beer in a single draught. I think he was a little disappointed by my failure to be spooked and put off by my prodding questions. I wanted to clarify some details in the tale, but he seemed frustrated that I was not willing to accept the tale without interrogating it. Mostly he seemed angry that I wanted to question how he told the tale, and why he chose certain ways of saying 
things. Why the word Indian and not the more commonly used and less controversial "native"? Had this "really happened" or was it "just a story"? How did his father come to be in Brent, and how long ago was this? I was sure the lodge had been closed long ago and wondered how the timeline of such a tale could work. But they turned the conversation around quickly and asked if I had any good stories to share.

They began asking me more about other stories I had heard, and I pointed out in passing that I was looking to find more helpful ways of talking to and about issues associated with settlerIndigenous relations. I said that I thought that there may be clues in ghost stories that could help us understand how we had come to where we are as a society and how we might do things differently. They began to press me, and the topic of land claims came up again, but this time in a more heated tone. I told them of the annual moose harvest held by the Algonquin that took place in the area, and how that provided food for a lot of families that would not otherwise have that kind of security.

At the time there was a news story about a blockade in Caledonia, and First Nations "protests" and the actions of land defenders in general had been making the news regularly that summer. I mentioned that I thought the Algonquin Nation's land claim, which encompassed a great deal of the Park, might be an opportunity, instead of a threat to the Park's existence. That the co-management of a conservation area had worked elsewhere and could work in Algonquin Park as well. The man in the red hat who had told the story stopped me mid-sentence and angrily blurted out "NOT UP HERE! Maybe you can find a way to do something different down there, but not up here. This is MY land."

Things got tense immediately. It became clear right away that though we were all nominally Canadian, I was outed as unpatriotic. They grew more restless and became more frustrated with me. I apologized and suggested that I should go. They agreed when I said I should go back to my campsite, and then the lead man stood up and said, "I'll walk you there."

I was nervous. I was alone in an isolated spot, and I had just found myself at odds with three men who were all much larger than me. I responded by saying that I was ok, but he insisted, saying that I didn't have a light. His two friends stood up from their seats and they all followed me back to my site, stopping a few paces away from the edge and standing in the middle of the road. The lead man again spoke up and said, "Sleep tight," before turning around and walking off with his pals into the darkness. My rest was uneasy at best that night, and I never really settled in to sleep. 


\section{Reflections in Waves}

Now, I have not been able to confirm that there was indeed a murder on the shores of Cedar Lake at that time. I may never be able to find out what happened there that night. The lodge is gone, a pile of ruins in the bush. Verification of what happened is unlikely. But I'm not sure that's the important thing to do with this tale and those like it: tales of the uncanny, the unspeakable, the unthinkable, and the monstrous. I am urged on by the suspicion that the importance of a tale is often less likely to be found in its content than in the context of its telling, the relationships affirmed, altered, and ended by such storytelling affairs.

Instead of questioning the men about the "truth" of the story, I took them at their word. Or at least instead of looking for a hidden meaning I trusted their interpretation of the events. I do think that something uncanny must have happened for this man's father to want to relate this tale to his young son, and to have done so in the same campgrounds years later suggests that he, like his father, felt an important connection to the place and a need to re-enact the initial telling. Perhaps he saw himself as an elder, a teacher, someone who could educate me about my proper relationship to the land as a settler, and to institute in me the same values he was raised with by celebrating the colonial control of the area. But what was most apparent in their demeanor and response to the unsettling threat I came to represent was that they felt deeply connected to the land through the idiom of possession, and that they felt protecting that possession was a mortal predicament. In this sense the ownership of place mimetically constructed through the practice of camping helped to construct an identity which required defense from the threat presented by a challenge to that authority over the land insinuated by the notion of sharing. Exposing the collusion between extractivism, colonialism and capitalist logics, their reactionary posture towards the ideal of communalism found in the idea of a comanaged conservation area demonstrated their embeddedness with the culture of possessive individualism and their willingness to do violence on behalf of the State. In no small way, the responses I received helped lay bare the pessimism of Canadian society towards the possibility of reconciliation between Indigenous and settler society, foreclosing any potential for an altered relationship to "the other," and insisting upon an always already "dead" future (Fisher 2008, 9); an authenticity of Canadian identity isomorphic with the imagination of a mythical past. Here, Mark Fisher's identification of Capitalist Realism coincides with the Canadian settler-colonial national-cultural imaginary to produce a cynical refusal of the potential for a relationship predicated on anything other than the destruction of the mythically constructed "Real Canadian"; to adulterate the phrase, it is easier to imagine the end of Canada than to imagine reconciliation (Fisher 2008, 9). 
The murderer could be understood as an allegory for the current state of Canadian consciousness surrounding Indigenous-settler relations. In this instance the murderer represents the always already absent "Native," the presumed representative of a past that serves only to impede settler-colonial possession of the land, and the murder itself stands in for the potential overthrow of the current settler-colonial order, the potential end of the country. Here, the Indigenous Person as guide semantically connects Indigeneity and nature, but also serves to re-instantiate a construction of Indigeneity as present only in an unchanging authenticity resigned to the past. Further, following Coll Thrush (2011), the connection drawn between the "drunken Indian" and vice as punishable sin plays out in the attempt to justify the erasure of Indigenous presence found in the sudden and unexplained disappearance of the Indigenous man in the story. Here, participation in practices introduced by EuroCanadian settlers is seen as metonymically nullifying one's claim to traditionalism and hence, to authentic Indigeneity. This in turn justifies in settler-colonial terms, the treatment of the now-formerly Indigenous Person as an "equal," a fellow laborer and a competitive theat.

The foundational act of primitive accumulation at the root of any capitalist effort takes place through the dispossession of Indigenous Peoples and their displacement from traditional lands, either physically or through the necromancy of private ownership and public property which transforms the commons into commodity, and the Indigenous Person into a proletarian laborer (Coulthard 2014). Under the contemporary neo-illiberal context this transformation is predicated on the notion of economic development in a cynically competitive mode of relation between nations. As demonstrated by Edward Goldsmith, "development is colonialism" insomuch as it requires the "modernization" of societies based on communal ownership and disposal of resources through the inculcation of possessive individualism and forced inclusion in the global economic order (Goldsmith 2001, 20). This pattern follows in the Park's creation and is further echoed in the official histories that recount loggers as paraheroic ancestors engaged in the subjugation of a threatening landscape, and which is simultaneously embodied in representations of Indigenous Peoples as doubly displaced; first, from the authenticity of an imagined past and second, from full inclusion in settler-colonial society because of their marked status as "Indian."

The anxiety provoked by the murder contained in the tale could serve to sublimate the threatening potential of a reinvigorated Indigenous presence on the land in the one telling the tale as well, offering some degree of explanation for the motives the camper with the red cap showed in retelling his father's grim tale. The presumption that colonial conquest is total and absolute seems premature when the recursive threat of First Nations "rising from the dead" is always shimmering on the edge of Canadian awareness, in the press, in the political domain, and sometimes, on the road during roadblocks and protests. Stories like this employ 
the necromancy of the state in service of an intentionally produced anxiety relating to Indigenous presence. But here it becomes necessary to reckon with the effects of being embedded within the discursive tradition one seeks to analyze. As indicated by the work of Jonathan Spencer, cultural analysts always participate in and through the cultures they critique, explaining that we are inescapably "writing within" these previously congealed national-cultural imaginaries (Spencer et al. 1990). The dialectical tension produced within these situations drives culture in divergent trajectories, affecting the production of selves and self-consciousness in unpredictable ways, though often boundaries are erected to be conditionally transgressed prompting a further defense of the status quo. This is how haunted recreation in this circumstance first enacts an appropriation of Indigenous culture through the construction of a mythologized past, then employs the threat of return as a driving force behind the necessity of progress construed as change which instantiates a further distancing from the repercussions of the original act of dispossession, and further appropriation of Indigenous culture.

\section{Walls Built to Fall}

The inability of Canadians to come to terms with the presence and persistence of Indigenous Peoples is a direct effect of the so-called "Garrison Mentality" first described by Gaile MacGregor in the Wacousta Syndrome (MacGregor 1995). Hiding behind tall walls and fortified cities, the hegemonic powers that governed political discourse for generations saw themselves as at odds with Indigenous Peoples. This retreat has become the de facto reaction of Canadians when challenged on the history of Canadian colonialism. The tale I was told metonymically instantiates Canadian resistance towards the notion of "reconciliation." It is a demonstration of the Wacousta Syndrome identified by MacGregor, but it is also a further example of Canadian settler-colonial erasure and violence. As Coll Thrush notes in his study of Seattle, dates and facts may be difficult to corroborate, "but [Indian ghosts] are not so much metaphors drawn from the imaginary of conquest as they are metonyms for the actual material processes by which that conquest" (Thrush 2011, 76) continues to take place. This perspective clarifies how haunting is primarily neither psychological nor spiritual, personal nor "place-based," but instead relational and vital as much as virtual; ghosts are with us in time. It also explains why I am less concerned with empirically verifying the events of the story than I am in understanding why he felt the desire to tell the probably apocryphal tale, and what the teller was trying to accomplish beyond intimidation. Of all the potential ways 
to offer me his opinion, why this way, and why the effort to convince me that it was a story passed down by his father?

The man who told the story was quick to cut me off and had no time or place for consideration of what I proposed. I feel that this is in part at least because of the advice he received from his father, advice which was embedded within the tale. The argument his father claims to have witnessed swells with meaning. It brings up questions regarding the status of the waring in Canadian settler-colonial society and the use of violent representations as boundary markers delimiting the acceptable limits of acceptable behaviour, the "mentionables." Here bodily integrity coincides with the ethno-nationalist imaginary, and the notion of penetration by an internal alien takes on predictable gravity under a regime of patriarchal domination where admitting difference amounts to admitting pathological infection of the national bodypolitic; the ring of fascist white supremacy comes into full relief in this tonic effort to erase the infarction. A ghost story is a warning not to engage with these dead spirits, and not to acknowledge their presence as "equals" in the sense of being worthwhile of reasoning with. The dead exist beyond reason. They summon emotion, and transmit affective intensities that alter experience, regardless of whether they can be measured as present in the moment or not. But more, they threaten to subdue any eruption of risk with the same violence, deeming all mention of legitimacy a joust at one's integrity punishable with overt violence. These stories need not be factual to have very tangible effects in the world. These stories summon erased and subjugated histories employed in the naturalization of the nation-state and the hegemony of Canadian settler-colonial ethno-nationalism, fraught with tension inherent in the arrangement of a "métis" society as described by John Ralston Saul, bound by a nagging desire to ignore the fullness of Indigenous Peoples' contributions and sacrifice for a nationstate set on their disappearance (Saul 2008).

These counter-narratives "talk back" to the "master narrative" constructed by officially sanctioned "History" (Stewart 1995, 97). They pit memory and emotion against claims of truth and fact, exposing the discipline of history as a political endeavor, and staking their claim to some portion of their own historical narrative (Gordon 1997). The ghost story works to shore up the margins of a territory occupied, but not legally "settled" since the RobinsonHuron Tract which includes much of the Park was negotiated and signed by peoples other than the Algonquin. Bubbling up alongside the rising tides of a neo-nationalist identification of the authentic Canadian as "white" the politically charged history of the Park, considering emerging contradictory histories and historical claims, serves as a paradoxical reminder of the simultaneous de facto status of Canadian sovereignty and the entrenched recognition of Aboriginal Rights and Title in the constitution. This arrangement troubles the desire for ethno-national purity and offers the ever-present possibility of Indigenous resurgence and 
territorial reclamation, conjuring Indigenous sovereignties from the mirage of a conquest accomplished. These conservative reactions to the ideas I spoke of in the conversation with these campers drew on the fears summoned by the conversations current at the time regarding the renewal of a nation-to-nation relationship. This relationship was notably floated by the Liberal Party of Canada in a savvy act piggybacking on the calls for a nation-to-nation relationship most prominently found in the popular imagery and music of the Indigenous musicians A Tribe Called Red.

Liberal calls for a renewed relationship with Indigenous Peoples predicated on calls for a nation-to-nation relationship drew on the activist discourse surrounding the defence of the land and the reclamation of culture associated with the Idle No More movement and in classic neoliberal fashion, reduced the concerns and voices of activists to a talking point ripe for appropriation and capitalization. In the wake of the election of Justin Trudeau to the leadership of the Federal Liberal Party the strategic shift towards a renewed interest in issues surrounding Indigenous-settler relations became clear with a pre-election micro-platform including a promise to address the decades old water quality issues affecting so many reserve communities in Canada. This shift in political language had stoked perennially elided conservative fears of Indigenous sovereignty and led to reinvigorated debate surrounding the need for greater economic opportunity, and perhaps the renegotiation of the Indian Act to allow houses on reserves to be owned privately, effectively reduplicating the efforts of the first Trudeau government's White Paper which sought to move away from the recognition of Indian Status entirely. Here rather than erasing the legal recognition of Status the government would encourage the private sale of reserve lands through transformation of houses into equity, and their use as collateral in loans that would inevitably often lead to default, foreclosure, and the passing of reserve lands into private hands. But the surge in attention towards Indigenous issues in Canada prior to the election of Justin Trudeau often redeployed the settler-colonial logic of paternalism and liberal individualism which simultaneously sought to "lift Indigenous Peoples out of poverty" while maintaining the relationship between the Crown and Indigenous Peoples which presumes settler dominance, as represented in the desire to reconcile "the pre-existence of aboriginal societies with the sovereignty of the Crown," while eliding that pre-existence as constituting Indigenous sovereignty (Asch 2014, 11). Indeed, during the summer of 2021 announcements of many unmarked graves on the sites of former concentration camps called Residential Schools throughout the country prompted greater attention but did little to help the shift away from the language of paternalism with many sympathetic Canadians voicing their concerns for "our" Indigenous Peoples online and in the media, expressing a subtly deployed notion of ownership over the generic "Indigenous Person," perpetuating the mythology of the white saviour. 


\section{Haunted Recreation}

Narrating their fear and hope through allegories, these three men told me in the ghost story of their connection to places that they know to be claimed by "others" and that could potentially become home to "other" ways of "doin'thangs" again. They held this fear at bay by displacing the reality of the threat into the past and thus sublimated the anxiety brought about by a less-than-conscious awareness associated with their participation in systems disenfranchising nearby neighbors they know are not doing any better than they are and the culpability of participating in the ongoing colonization of Algonquin territory. But also, of the "public secret" of the ongoing genocide against Indigenous Peoples in Canada (Taussig 1999). Translating their fear into an apparition of monstrous threat, these men summon demons and become the vessel for their voices, welcoming possession by arcane and ancient forces. For the old man in the cemetery, the authorities who dismiss his claim to the place by obfuscating his claim to belonging become distant boogeymen, eliding the continuity of his families' claims, and threatening his nephews' future inheritance. For Jake and Rob, The Mayor still roams his house, protecting the memory that was defiled by his families' actions. They hope for better for themselves, but expect the worst, and their grim humour embodies a form of narcotic resilience.

This is haunted recreation (Puppe 2012, unpublished); the recreation of selves and subjectivities which take place through immersive experiences in spaces marked by nostalgic longing, ruin, and the violence of "progress," genocide and obsolescence in the most quotidian contexts (Ivy 1998, 3; Stewart 1995). Haunted recreation brings together concerns with tourist studies in settler-colonial spaces imbued with memorial intensity and studies of labor and affect by examining how the work of imagining the nation is enacted even during our most leisurely moments, beyond "dark tourism" (Miles 2015) and the racist connotations of connecting darkness with the negative, while examining instead the productive capacities of the seemingly absent to affect and be affected by people on an intimate and informal scale.

The buried treasure that Rob joked about was there to lure others into their world, and into the bush, far from the cities and towns near the Park. That scent marked the history of the place, the railway bed itself, and the spot where I would later learn that a buried oil tank had split while being hoisted from the ground, staining the soil, leaving the water table compromised. But the Mayor called out for attention as well, not because he was caught in limbo, unable to rest, but because he summoned a kind of care that seemed to be vanishing in each mention of his effort, and his sacrifice. "Uncle Romeo," as the old man I met at the grave site had called his buried uncle, spoke a counter-narrative to the displacement of pain and effort spent caring for the village and the land which was washed away in the tide of 
official records; nine bodies, drowned by a logjam broken lose, or one body, his ancestor... what if there are ten?

The story the old man told to his nephews was meant to intensify their connection to the place and to instantiate their personal and inherited connection to that spot. And the murder on the beach is meant to dissuade those who would falter in their claims to ownership of this place, or any other place they wrestled away from people thought of as different enough. It kills the possibility of a future together. But it is not a widely known story. I have only heard it from one man, who may well have made it up on the spot. I don't think that makes it less important, or less of an historical artifact. Rather, its ephemerality speaks to the intransigence of fear and the embodiment of a culturally conditioned response to a national threat; the story embodies conservative reactionary posturing and the mythologization of Indigeneity as the inverse of settler-colonial civilization and seeks to summon such fears in the listener by eliding the possibility of rational escape from the terror it transports.

My inability to corroborate the facts of the murder, to determine the date, or even if anyone has ever been killed there, demands something more than a search for simple and empirically verifiable truths. It demands of me to feel the possibility, and the looming potentiality, that each threat will be composed as mortal through a zero-sum calculation of a paradigmatically colonial capitalism. Combatting the Garrison Mentality of the Wacousta Syndrome and the socio-personal complex of haunted recreation is central to combatting the anaesthetized subjectivity of the Canadian settler-colonist and reviving the dream of reconciliation.

Haunted recreation allows settlers to spend great sums of money and time travelling hours from their homes to spend days and sometimes weeks in places that have been cleared of Indigenous presence, and reclaimed as "pristine," "natural," and "untouched," only to reaffirm the moral superiority of settler-colonial society through the presentation of protected area as signs of national virtue. These representations of idyll Canada are counterposed in news images and common conversations where Indigenous Peoples are manufactured to appear less able to protect the land. When the subject of the moose harvest arose, the response from one man was "huh, for how long?" And when the potential return of Indigenous stewardship came up in relation to the land claim the overt sentiment among the men was that Indigenous Peoples would allow the Park to fall into ruin. "Have you ever been to the reserve?"; an all-too-common refrain from conservative leaning rural and near-northern residents from my years of experience. The insinuation of course being that settlers would be immeasurably better and more conscientious stewards of the environment. That the same people responsible for building a railroad through the Park to log and mine, to trap and fish, and to extract the solace and peace of such seemingly untended places by building cottages, 
lodges, cabins, and then letting them fall into disrepair and eventually allowing the toxic materials they are composed of return to the soils in a protected place, would unquestionably make for more rational guardians of the land.

\section{Conclusion}

Disrupting the comfort gained through recreational practices unsettles Canadian historical claims and simultaneously exposes local counter-narratives as more or less aligned with ascendant forms of North American ethno-nationalism, xenophobia, and white supremacy. Attending to these stories as oral histories allows us to momentarily move past issues of verification, and to interrogate the politics underlying the telling of these tales as they emerge in contexts always inflected by national-cultural imaginaries (Ivy 1998, 3), fears and desires. Through the violence of haunted recreation, the land is cleared of all but the most lucrative signs of Indigeneity, which in turn become appropriated as signs of authentic Canadian culture; camping, fishing, hunting, and spending time on the waters, all lifestyle attributes of Indigenous societies oriented around sustainable relations with the land and its' resources, more properly understood through the idiom of kinship in Anishinaabe relational ontologies. The abdication of responsibility by settler-colonial society towards sustainable Treaty-based, nation-to-nation relationships with Indigenous Peoples and the land stands as the ultimate failure of Canadian society. And it is the reconciliation with such failures to self-scrutinize the roots of our reactionary tendencies that holds the most promise moving forward, combatting the monstrous violence that undermines Indigenous sovereignty in Canada in the wake of neo-illiberal and neoconservative retreat.

A popular keepsake often purchased at the Algonquin Park Visitor Centre and Museum located along the Highway \#60 corridor which runs through the southern end of the Park is a photobook called "Algonquin: The Park and Its People" (Standfield and Lundell 1993). It contains numerous images of emptied landscapes juxtaposed with portraits of important figures from the Park's past and present: rangers, wardens, farmers, loggers, and campers. But it too participates in the unfortunate pattern of eliding the presence, historical and contemporary, of the Algonquin Anishinaabe. On the first page a haunting image of a paddler silhouetted against a dimly lit lake and a dark forest is accompanied by a quote taken from an interview with a former Park Ranger named Jimmy Coughlin. Coughlin says, "With all the ghosts that haunt the Park, I wonder how many of them travel the canoe routes looking for the old ranger cabins" (Standfield and Lundell 1993, 2) I know that the Algonquin still walk and care for these forests and waters. I speak with them and witness their care for the 
Ian PUPPE

"With All The Ghosts that Haunt the Park...": Haunted Recreation in Brent (Ontario)

place. I am forced to wonder though, how many of these ghosts paddle the lakes and streams, and walk the woods, looking for signs of a world long passed, and how we might begin to hear those other voices to help them find their place in our collective memory, and our future.

\section{References Cited}

Asch, Michael. 2014. On Being Here to Stay: Treaties and Aboriginal Rights in Canada. Toronto, O.N.: University of Toronto Press.

Coulthard, Glen Sean. 2014. Red Skin, White Masks: Rejecting the Colonial Politics of Recognition. Minneapolis, M.N.: University of Minnesota Press.

Fisher, Mark. 2009. Capitalist Realism: Is There No Alternative? Washington: Zero Books.

Goldsmith, Edward. 2001. "Development as Colonialism." In The Case Against the Global Economy and for A Turn Towards Localization, edited by Jerry Mander and Edward Goldsmith, 19-34. London: Routledge.

Gordon, Avery. 1997. Ghostly Matters: Haunting and the Sociological Imagination. Minneapolis, M.N.: University of Minnesota Press.

Ivy, Marilyn. 1998. Discourses of the Vanishing: Modernity, Phantasm, Japan. Chicago, I.L.: University of Chicago Press.

MacGregor, Gaile. 1985. The Wacousta Syndrome: Explorations in the Canadian Langscape. Toronto, O.N.: University of Toronto Press.

Miles, Tiya. 2015. Tales from the Haunted South: Dark Tourism and Memories of Slavery from the Civil War Era. Chapel Hill: University of North Carolina Press.

Puppe, lan Sorjo Grant. 2012. Shivering in Brent, Ontario: Haunted Recreation in Algonquin Provincial Park. Unpublished Master's Thesis. Toronto, O.N.: York University.

Saul, John Ralston. 2008. A Fair Country: Telling Truths about Canada. Toronto, O.N.: Penguin Canada.

Spencer, Jonathan, Richard Handler, Bruce Kapferer, R. S. Khare, Dennis B. McGilvray, Gananath Obeyesekere, Daniel A. Segal, and Martin Southwold. 1990. "Writing Within: Anthropology, Nationalism, and Culture in Sri Lanka [and Comments and Reply]." Current Anthropology 31 (3): 283-300.

Standfield, Donald, and Liz Lundell. 1993. Algonquin: The Park and Its People. Toronto, O.N.: McClelland and Stewart Inc. The Canadian Publishers. 
Stern, Pamela. 2019. "The Ghosts of Mining Past: A Settler Colonial Story." Anthropology and Humanism 44 (2): 231-247.

Stewart, Kathleen. 1996. A Space on the Side of the Road: Cultural Poetics in an "Other" America. Princeton, N.J.: Princeton University Press.

Taussig, Michael. 1999: Defacement: Public Secrecy and the Labor of The Negative. Stanford, C.A.: Stanford University Press.

Thrush, Coll. 2011. "Hauntings as Histories: Indigenous Ghosts and the Urban Past in Seattle." In Phantom Past, Indigenous Presence: Native Ghosts in North American Culture \& History, edited by Colleen Boyd and Coll Thrush, 54-82. Lincoln, NB: University of Nebraska Press.

lan Puppe is an Assistant Professor of Native Studies at Brandon University in Manitoba. Puppe received his doctorate in Anthropology from The University of Western Ontario after completing his masters and undergraduate degrees in Anthropology at York University in Toronto, Ontario. He has taught the anthropology of media, Indigenous/First Nations/Native Studies, and Global Studies, as well as Social and Cultural Determinants of Health and Aboriginal Health. Puppe's research focuses on the socio-cultural relations between people and

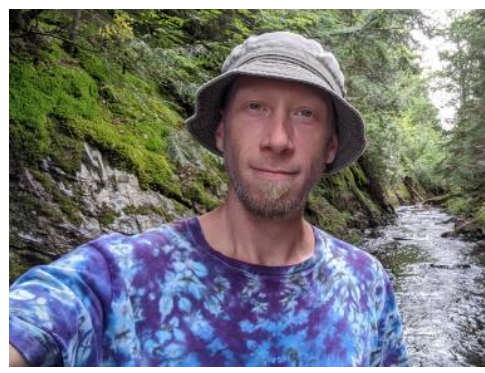
protected places, national, and provincial parks in Canada and their political implications. Puppe received a Philip's Fund Fellowship from the American Philosophical Society and is a post-doctoral research partner on the Social Science and Human Research Council (SSHRC) funded Franz Boas Papers Digital Documentary Project and research lead for the Sioux Lookout Zone Hospital Archives Project (with Dr. Gerald McKinley of the Schulich School of Medicine and Dentistry and Dr. North de Pencier, MD). Puppe's notable publications include "When the Bough Breaks: Balancing Heritage, Forestry, and Unsustainable Standards in Algonquin Provincial Park," (2021) in Dalhousie's Technoscience and Regulation Research Unit's (TRRU) Canadian Institute for Health Research (CIHR) funded edited volume entitled "The Social Life of Standards: Ethnographic Methods for Local Engagement," Janice Graham, Christina Holmes, Fiona MacDonald \& Regna Darnell [eds.], University of Toronto Press, and "Sioux Lookout Zone Hospital Archives Project Barriers in Bringing Medical Anthropology to Medical Practice: Adrian Tanner, the Sioux Lookout Zone Hospital and Cross-Cultural Miscommunication," (2021) (with North De Pencier \& Gerald McKinley) in Histories of Anthropology Annual (HoAA), Vol. 14, Regna Darnell and Frederic Gleach (eds.), University of Nebraska Press. 